\title{
Flow Behavior and Microstructure Evolution of Ti- 6Al-4V Titanium Alloy Produced by Selective Laser Melting Compared to Wrought
}

\section{Denis R Salikhyanov ( $\nabla$ d.r.salikhianov@urfu.ru )}

Ural Federal University named after the first President of Russia B N Yeltsin: Ural'skij federal'nyj universitet imeni pervogo Prezidenta Rossii B N El'cina https://orcid.org/0000-0001-7235-7111

\section{Valeriya E Veselova}

FSBIS Institute of Engineering Science Ural Branch of the Russian Academy of Sciences: FGBUN Institut masinovedenia Ural'skogo otdelenia Rossijskoj akademii nauk

\section{Vladimir P Volkov}

FSBIS Institute of Engineering Science Ural Branch of the Russian Academy of Sciences: FGBUN Institut masinovedenia Ural'skogo otdelenia Rossijskoj akademii nauk

\section{Research Article}

Keywords: additive manufacturing, selective laser melting, titanium alloy, Ti-6Al-4V, microstructure, flow stress

Posted Date: July 9th, 2021

DOl: https://doi.org/10.21203/rs.3.rs-293851/v1

License: (9) This work is licensed under a Creative Commons Attribution 4.0 International License. Read Full License

Version of Record: A version of this preprint was published at The International Journal of Advanced Manufacturing Technology on November 12th, 2021. See the published version at https://doi.org/10.1007/s00170-021-08000-7. 


\section{Abstract}

Nowadays, selective laser melting (SLM) represents an option for manufacturing parts from titanium alloys, especially from Ti-6Al-4V alloy. However, mechanical properties of parts made of Ti-6Al-4V such as ductility and fatigue resistance are significantly lower than that for conventional manufactured parts. One of the promising ways to improve mechanical properties of SLM parts can be the use of deformation post-processing, for example, combining SLM with subsequent die forging.

Therefore, the aim of the present study is to investigate the rheological properties and microstructure evolution of Ti-6Al-4V titanium alloy fabricated by SLM under temperatures of cold and hot deformation. The tests of cylindrical samples made of Ti-6Al-4V alloy was performed using a plastometer in the temperature range of $20-1200{ }^{\circ} \mathrm{C}$, at strain rate $\xi$ of $1 \mathrm{~s}^{-1}$ up to strain $e$ of 0.85 . To evaluate the effect of manufacturing method of samples on flow behaviour and microstructure evolution of the material, the samples made of Ti-6Al-4V alloy fabricated by conventional technology were tested under the same conditions.

The differences in the flow behaviour of SLM and conventional manufactured samples from Ti-6Al-4V which were significant at test temperatures of $20-900{ }^{\circ} \mathrm{C}$ were analysed and explained. In contrast to conventional manufactured parts, SLM-produced Ti-6Al-4V reveal higher peak stresses in the flow curves and temperature sensitivity of flow stresses. This in turn leads to high inhomogeneity of deformation of SLM-produced parts.

\section{Introduction}

Additive manufacturing (AM), the layer-by-layer building-up of parts from metals and alloys represents an option for small scale production due to advantages compared to conventional manufacturing such as reduction in lead-time, reduced material wastage, freedom in the design of the parts [1-8]. The opportunity of manufacturing of metal parts of any complexity in a short term is especially important in aerospace and medical industries, since their manufacturing via conventional technologies including casting, metal forming and subsequent machining is expensive and time-consuming process. In these industry fields, Ti-6Al-4V titanium alloy is of great interest due to its high strength, low density, excellent corrosion resistance and biocompatibility [8-10]. Approximately $50 \%$ of all titanium alloys used in aerospace fall to the lot of Ti-6Al-4V alloy. Among different methods of AM of parts from Ti-6Al-4V alloy, selective laser melting (SLM) is widely used [9-19].

In view of this, the study of strength, plastic and fatigue properties of SLM-produced Ti-6Al-4V alloy and its applicability for responsible parts is of special interest $[8,9,11,12,13,15,16,20-28]$. Table 1 presents a summary of the mechanical properties of Ti-6Al-4V alloy produced by SLM of different conditions initial condition (as-built) not machined, machined, stress-relieved, annealed, after hot isostatic pressing (HIP) in comparison with material produced by conventional manufacturing methods - cast, wrought, 
wrought and mill annealed. Spread in values in Table 1 is explained by choice of different process parameters.

As can be seen from Table 1, strength properties of as-built SLM-produced Ti-6Al-4V alloy without any post-treatment are comparable with those for wrought material, but ductility and fatigue life are significantly lower. Heat treatment allow to slightly improve ductility and fatigue life of SLM-produced Ti$6 \mathrm{Al}-4 \mathrm{~V}$, however their values still less than those for wrought Ti-6Al-4V. Besides, it must be noted greater spread in values of mechanical properties of SLM-produced Ti-6Al-4V. To make both ductility and fatigue life of SLM-produced Ti-6Al-4V comparable to wrought, special treatment by HIP is necessary. HIP allows removing bulk defects, undesirable martensitic microstructure, porosity, residual stresses which are typical for as-built SLM-produced Ti-6Al-4V [7, 8, 29]. However, HIP is very expensive process due to high equipment cost, besides it's necessary to note limitations related to treatment of large-scale parts [30].

As shown above, in order to improve the mechanical properties and reliability of parts produced by SLM, a thermo-mechanical post-treatment is necessary. An alternative to SLM with subsequent HIP can be a combination SLM with deformation post-treatment. One strategy is presented in [31-36]. In [31], the technology of AM including plastic deformation each built-up layer by the roller is suggested. This method provides better mechanical properties for Ti-6Al-4V in comparison with wrought alloy. In [32, 33], the method of ultrasonic AM which includes rolling each built-up layer by the roller with oscillation along its axis is presented. In [36], deformation is suggested to be applied by a hammer immediately after deposition. Described methods of deformation post-treatment allow decreasing grain size and porosity in AM-parts.

Another strategy is described in [37-39]. Semiatin S.L. [37], Sizova I., Bambach M. [38, 39] suggested novel processing route "AM + hot forming" consisting of two stage. At the first stage, an appropriate preform from Ti-6Al-4V is produced by SLM and at the second one, built pre-form undergoes die forging with the aim to obtain final dimensions and mechanical properties of the part. This method is of special interest because it combines advantages of SLM and die forging. On the one hand the processing route "SLM + hot forming" compared to conventional route "cast + forging + machining" provides significant reduction of processing route steps, reduction in lead-time and in material wastage at the same level of mechanical properties of parts, on the other hand suggested processing route compared to SLM provides high performance characteristics without expensive downstream post-processing by HIP. Processing route "SLM + hot forming" is especially efficient for producing parts from Ti-6Al-4V titanium alloy but applicable for large-scale and mass production.

To develop this approach, it is necessary to know stress-strain curves, flow behaviour and microstructure evolution of Ti-6Al-4V alloy. There are several studies related to rheological properties of AM Ti-6Al-4V alloy $[8,11,13,15,37,38,39]$. In $[8,11,13,15]$, tensile curves at room temperature of SLM-produced Ti$6 \mathrm{Al}-4 \mathrm{~V}$ are presented only. Such tests are carried out at room temperature up to strains e equal to 0.120.15 and don't correspond to hot working conditions. In [37], stress-strain curves of laser-deposited Ti-6Al$4 \mathrm{~V}$ obtained via hot compression method at temperatures from 815 to $1010^{\circ} \mathrm{C}$, at strain rates $\xi$ of 0.1 
and $5.0 \mathrm{~s}^{-1}$ up to a true strain $e$ of 0.9 are given. In [38, 39], stress-strain curves of SLM-produced Ti-6Al$4 \mathrm{~V}$ obtained via hot compression method at temperatures from 850 to $1000^{\circ} \mathrm{C}$, at strain rates $\xi$ from 0.001 to $1.0 \mathrm{~s}^{-1}$ up to a true strain $e$ of 0.9 are presented. Besides, it is worth to mention the stress-strain curves of conventional manufactured Ti-6Al-4V in [40-50]. Bambach and Sizova [38, 39] reported that flow stresses of SLM-produced Ti-6Al-4V show lower values than that of conventional wrought in the temperature range of $850-950^{\circ} \mathrm{C}$. This can relate to a different initial microstructure of SLM-produced and conventional wrought materials.

Published studies on stress-strain curves of SLM-produced Ti-6Al-4V was made under isothermal condition in the temperature range $850-1000^{\circ} \mathrm{C}$, however the difference in temperatures in individual regions of the parts during die forging (which is typically non-isothermal process) may be large and reach values of $100-160^{\circ} \mathrm{C}[45,51]$. In turn, a large temperature gradient leads to an inhomogeneous deformation of forgings. For this reason, the aim of this study is to investigate the flow curves and flow behaviour of SLM-produced Ti-6Al-4V alloy in the wide temperature range in comparison with conventional wrought Ti-6Al-4V alloy. In addition, microstructure evolution, softening rate and temperature sensitivity of SLM-produced Ti-6Al-4V also were assessed. This data can be used in the design of processing route "SLM + hot forming" of parts from Ti-6Al-4V alloy.

\section{Materials And Methods}

Cylindrical samples from Ti-6Al-4V titanium alloy were fabricated on an EOSINT M 280 additive machine by SLM method at the Regional Engineering Centre of Additive Technologies of Ural Federal University. Axis of the samples was parallel to the build direction. For producing titanium alloy samples, laser power was equal to $200 \mathrm{~W}$, a scan speed was equal to $2 \mathrm{~m} / \mathrm{s}$, powder with spherical morphology and particle size 20 - $35 \mu \mathrm{m}$ was used. Chemical composition of Ti-6Al-4V alloy (EOS's data) is given in Table 2. Samples from SLM-produced Ti-6Al-4V alloy were tested in as-built condition, without machining.

In order to compare the flow curves and flow behaviour of Ti-6Al-4V alloy obtained in different ways and to evaluate the effect of manufacturing method, samples made of titanium alloy VT6, which is Russian analogue of Ti-6Al-4V alloy, were also tested under the same conditions. Chemical composition of VT6 alloy is also given in Table 2. Samples from VT6 alloy were fabricated from hot-rolled and annealed bars. For convenience, we will assume hereinafter that VT6 alloy is wrought Ti-6Al-4V.

Cylindrical samples from Ti-6Al-4V alloy $10 \mathrm{~mm}$ in diameter and $14 \mathrm{~mm}$ in height, samples from VT6 alloy $10 \mathrm{~mm}$ in diameter and $15 \mathrm{~mm}$ in height were used for hot compression testing.

Flow curves of Ti-6Al-4V alloy produced by SLM and conventional technology were studied using the cam plastometer with a working force up to $1500 \mathrm{kN}$ placed at the collective use centre «Plastometriya» of the Institute of Engineering Science of the Ural Branch of the Russian Academy of Sciences by isothermal hot compression of cylindrical samples according to the procedure described in [52 - 53]. Hot compression tests of the samples were carried out in the temperature range of $20-1200$ 
${ }^{\circ} \mathrm{C}$ with heating of the samples and dies from room temperature. The strain rate $\xi$ was equal to $1.0 \mathrm{~s}^{-1}$ and was held constant during the whole process of compression due to the corresponding cam profile and automated regulated electric drive. Characteristic temperatures for Ti-6Al-4V alloy are: $450-550{ }^{\circ} \mathrm{C}$ - ageing temperature; $800{ }^{\circ} \mathrm{C}$ - annealing temperature; $850-950{ }^{\circ} \mathrm{C}$ - recrystallization temperature; 995 ${ }^{\circ} \mathrm{C}-\beta$ transus temperature [40].

Before loading into the furnace for heating, samples were placed into a special cylindrical container (Fig. 1) on a centre of deforming anvils made of special heat-resistant alloy and insulated with kaolin wadding. Container is used in order to maintain temperature during testing. Temperature measurements on the sample surface inside the container with the use of thermocouple show that temperature is held constant during $10-20 \mathrm{~s}$, so hot compression test which takes much less time can be considered as isothermal. To provide the uniform compression and uniaxial compressive stress state at temperatures above $700{ }^{\circ} \mathrm{C}$, a lubricant in the form of ground glass containing $55 \% 55 \% \mathrm{SiO}_{2}, 7 \%$ $\mathrm{BO}_{2}, 21 \% \mathrm{Al}_{2} \mathrm{O}_{3}, 14 \% \mathrm{CaO}$ was used, at temperatures below $700{ }^{\circ} \mathrm{C}$ a graphite lubricant was used.

Heating samples to test temperatures was performed in an electric furnace along with the container until a uniform temperature was achieved throughout the cross section of the sample.

After attaining a specified temperature, container with a sample is extracted from the furnace and placed into a working place of the plastometer on the load cell along its axis, then the sample is immediately compressed with an automatic registration of current height and force on a computer. Registered compressing parameters is processed using a program by formula $\sigma_{s}=P / F$, where $P$ is the measured force, $F$ is the calculated cross section area. As a result, the flow curves of the materials were obtained.

Additionally, metallographic studies of the samples made of SLM and wrought Ti-6Al-4V alloys after etching in the agent $\left(20 \mathrm{ml}\right.$ of $\mathrm{HF}+20 \mathrm{ml} \mathrm{HNO}_{3}+60 \mathrm{ml}$ of water) were performed by means of optical metallography. Their microhardness was also measured on microhardness tester with an integrated optical microscope Shumadzu HMV-G21DT.

\section{Results And Discussion}

\subsection{Initial microstructure of SLM-produced and wrought Ti- 6Al-4V}

Results of the study of the microstructure of SLM-produced and conventional wrought Ti-6Al-4V alloy on an optical microscope are presented in Fig. 2. Figure 2a, b presents the microstructure of wrought Ti-6Al$4 \mathrm{~V}$ alloy without and with etching respectively, Fig. 2c, d - the microstructure of SLM-produced Ti-6Al-4V alloy without and with etching respectively. From Fig. $2 a, b$ it is seen that in the microstructure of wrought Ti-6Al-4V alloy the grains of initial $\beta$-phase are not noticeable, boundaries of $\beta$-grains are not expressed, strongly marked a-colonies are absent. a-phase laths intersect between themselves forming peculiar pattern "basket weave". 
From Fig. 2c, d it is seen that the microstructure of as-built SLM-produced Ti-6Al-4V alloy consists of a fine needle-shaped a $\mathbb{\|}$-phase divided by interlayers of $\beta$-phase inside the elongated $\beta$-grains. The microstructure shows that $\alpha$-phase is fine enough because of high cooling and crystallization rate. The same observations were made in studies $[9,11,15,38,39]$. Grains of $\beta$-phase are elongated in one direction, along the direction of grain growth during SLM process. This can lead to the anisotropy of properties, low level of plasticity and cyclic load resistance.

In the SLM-produced parts, in addition to the specific structure, defects may be present - mainly voids and lack of fusion [54]. Although no voids and microcracks were detected on the sample surface by optical microscopy, in $[8,26]$ it is reported that porosity is actually very common in SLM-produced parts. A porosity of $0.23 \%$ in SLM-produced samples was detected with the use of X-ray tomography in [26], porosity of $0.023-0.37 \%$ in [8]. Vickers microhardness HV is 367 for SLM-produced Ti-6Al-4V alloy, and 337 for wrought Ti-6Al-4V alloy.

\subsection{Flow behaviour of SLM-produced and wrought Ti-6Al- 4V}

Flow curves of SLM-produced and conventional wrought Ti-6Al-4V titanium alloy in the form of dependence of flow stress $\sigma_{\mathrm{s}}$ on true strain $e\left(e=\ln \left(h_{0} / h_{i}\right)\right.$, where $h_{0}$ and $h_{i}$ are initial and current sample height, respectively) are presented in Fig. 3 at different test temperatures. From Fig. 3b, c, it is seen that the flow stresses of as-built SLM-produced material higher than that of conventional wrought in the temperature range from 600 to $900^{\circ} \mathrm{C}$, i.e. when deformation occurs in $(a+\beta)$-field. Moreover, at these temperatures flow stress behaviour of SLM and wrought material is different - SLM-produced Ti-6Al-4V shows pronounced peak stress with subsequent intensive softening. Due to intensive softening of SLM material, its flow stress can even become less than that of wrought material - at temperature of $600{ }^{\circ} \mathrm{C}$ and strain of 0.38 and above, at temperature of $700{ }^{\circ} \mathrm{C}$ and strain of 0.34 and above, at temperature of $800^{\circ} \mathrm{C}$ and strain of 0.39 and above. The difference in the values of flow stresses of both materials is increasing with decrease in the deformation temperature. Flow curves of SLM-produced Ti-6Al-4V alloy were compared with the ones of SLM Ti-6Al-4V and Ti-6Al-4V with martensitic microstructure of other authors $[38,39,42,44]$. Comparison with the published studies shows similar flow behaviour and values of flow stresses under the same thermomechanical condition.

Differences in the values of flow stresses and flow behaviour of SLM-produced and conventional wrought materials are well explained by their initial microstructure. According to [41, 44], the flow stress increases with decreasing in a-lath thickness due to the Hall-Petch effect, therefore samples with martensitic microstructure (SLM-produced) will have higher level of flow stresses than the ones with lamellar microstructure (wrought) under the same test condition. From Fig. 2, approximate a-lath thickness of SLM-produced Ti-6Al-4V alloy is less than $1 \mu \mathrm{m}$, while approximate a-lath thickness of wrought Ti-6Al-4V alloy is in the range of $2-5 \mu \mathrm{m}$.

Flow stresses of SLM and wrought materials are close to each other in the temperature range from 1000 to $1200{ }^{\circ} \mathrm{C}$, i.e. when deformation occurs in $\beta$-field. This observation is in agreement with $[37,38,39]$. Both 
material under deformation in single $\beta$-field exhibit nearly steady-state stresses and no softening. This phenomenon probably related to dynamic recovery [40]. It is also worth to mention that final die forging in $\beta$-field is undesirable because of coarse final microstructure of the parts.

As was mentioned above, flow curves of SLM-produced Ti-6Al-4V alloy exhibit pronounced peak stress at temperatures of $600-900{ }^{\circ} \mathrm{C}$ and at strains of $0.09-0.12$ with subsequent long stage of softening. Peak stresses are explained by the following. XRD analysis of as-built SLM-produced Ti-6Al-4V alloy performed by Facchini et al. [15] indicates the presence of hexagonal close packed (hcp) phase only. Limited number of slip modes inherent in the hcp-lattice in turn lead to sharp hardening and presence of peak stress $[41,47]$. The flow softening observed in flow curves for SLM-produced Ti-6Al-4V alloy (Fig. 3b, c) is a consequence of commonly two possible sources - due to deformation heating and microstructure changes $[40,47]$. The latest consists of changes in phase morphology, substructure, and texture. From point of view of theory analysis, in $[41,55]$ it was suggested that flow softening is a result of the loss of Hall-Petch strength associated with $(a+\beta)$ interfaces.

\subsection{Deformation behaviour and temperature sensitivity of SLM-produced and wrought Ti-6Al-4V}

General view of the samples from as-built SLM-produced and conventional wrought Ti-6Al-4V after deformation at different temperatures is presented in Figs. 4 and 5 respectively. As seen in Fig. 4, SLM samples have fractured at temperatures of 20,400 and $500^{\circ} \mathrm{C}$. At temperatures of $600-800^{\circ} \mathrm{C}$, an extremely non-uniform deformation of SLM samples occurs: at temperature of $600^{\circ} \mathrm{C}$ offset of one end of the sample relative to the other was observed, at temperatures of 700 and $800{ }^{\circ} \mathrm{C}-$ a double barrel formation. At temperatures of $900-1200^{\circ} \mathrm{C}$, deformation of SLM samples was quite uniform, dimensions of barrel lay within the normal limits.

Figure 5 show that deformation of wrought material in the whole temperature range of $400-1200^{\circ} \mathrm{C}$ was quite uniform: no fracture and non-uniformity of deformation inherent to SLM material were observed. Wrought material has fractured at temperature of $20^{\circ} \mathrm{C}$ only.

Described features of deformation behaviour of SLM-produced Ti-6Al-4V at temperatures of $20-800{ }^{\circ} \mathrm{C}$ and especially reasons for such behaviour is of practical interest because this can lead to defects and quality impairment of final parts after hot forming operations. Possible reasons can be ascribed to the initial martensitic microstructure, anisotropy of properties, residual stresses and defects of SLM-produced material. Bambach et al. [39] show the anisotropy has negligible effect on the flow behaviour via hot compression testing of samples with different building direction. The most probable reason is the following. As seen in Fig. 4, the samples failed at temperatures of 20,400 and $500{ }^{\circ} \mathrm{C}$ by shear fracturing. It's obvious that the shear crack occurs at an angle of $45^{\circ}$ relative to the load direction. Li et al. [56] show that this type of fracture is initiated by the onset of intense flow instabilities caused by adiabatic shear band formation. Adiabatic shear bands are observed at temperatures up to $600{ }^{\circ} \mathrm{C}$. Moreover, microstructure analysis revealed that void defects and lack-of-fusion pores inherent to SLM material are likely to become the nucleation sites for adiabatic shear bands and microcracks [56, 57]. 
High plastic flow instability at temperatures of $700-800^{\circ} \mathrm{C}$ of SLM material compared to wrought is a consequence of its high temperature sensitivity (Fig. 6) and softening rate (Fig. 7). In Fig. 6, it is seen that SLM-produced Ti-6Al-4V is more sensitive to deformation temperature than conventional wrought. At the same non-uniformity of temperature $\Delta \mathrm{T}$, SLM material will have higher non-uniformity of stresses $\Delta \sigma$ than wrought material. Besides, non-uniformity of stresses $\Delta \sigma$ will increase with decrease in deformation temperature T. Since processes of die forging are typically non-isothermal processes, temperature sensitivity of SLM material must be taken into account when designing processing route.

Another factor which enhances flow instability is softening rate (Fig. 7). Softening rate can be determined by $\sigma_{\mathrm{p}} / \sigma_{\mathrm{ss}}$ ratio suggested in [58], where $\sigma_{\mathrm{p}}$ - peak stress, $\sigma_{\mathrm{ss}}$ - steady state stress. It is known that more uniform deformation is observed for hardening materials. Since the flow stresses increase in the deformed zones of material during compression, further deformation occurs in the non-hardened zones. Due to this phenomenon the deformation distribution in the blank becomes more uniform. There is reverse situation for softening material - deformed zones of material become softer, so further deformation occurs in the same deformed zones forming high deformation gradient. This phenomenon is also described in [43]. In Fig. 7, it is seen that SLM material is highly softening material in comparison with wrought $-\sigma_{\mathrm{p}} / \sigma_{\mathrm{ss}}$ ratio is 2 times greater than that of wrought at temperature of $700{ }^{\circ} \mathrm{C}, 1.5$ times greater at temperature of $800{ }^{\circ} \mathrm{C}, 1.16$ times greater at temperature of $900{ }^{\circ} \mathrm{C}, 1.06$ times greater at temperature of $1000^{\circ} \mathrm{C}$.

To illustrate the differences in deformation gradient between SLM-produced and wrought material, simulation by finite-element method (FEM) was made in the program Deform - 3D. For FEM-simulation, process of isothermal compression of samples from SLM and wrought Ti-6Al-4V alloy was accepted, obtained flow curves of both materials (Fig. 3) were used. Boundary conditions corresponded to conditions of real compression of SLM and wrought samples (Sect. 2). Deformation gradient was obtained for wrought (Fig. 8, a) and SLM-produced (Fig. 8, b) samples at temperature of $900{ }^{\circ} \mathrm{C}$. In Fig. 8, highly inhomogeneous deformation can be observed for SLM-produced Ti-6Al-4V - after deformation strain effective in the centre of the sample is 1.2 , on the end -0.2 , while strain effective in the centre of the wrought sample is 0.9 , on the end -0.3 . It is obvious that at lower deformation temperatures, the deformation inhomogeneity will be even more pronounced. Based on this, it is necessary to control the temperature in the deformation zone for the processes of deformation post-treatment in-situ (plastic deformation of each built-up layers) and apply isothermal die forging for the processing route "SLM + hot forming".

\subsection{Microstructure of SLM-produced and wrought Ti-6Al-4V after deformation}

As shown in Sect. 3.1, initial microstructure of wrought Ti-6Al-4V represents "basket weave" of a-laths, while initial microstructure of SLM-produced Ti-6Al-4V - a囚-martensite inside $\beta$ grains elongated along building direction. 
After deformation in $(a+\beta)$-field, globularization of wrought Ti-6Al-4V occurs (Fig. 9a, c, e, g) - partially at deformation temperature of $800^{\circ} \mathrm{C}$ (Fig. 9a, c); completely at deformation temperature of $900{ }^{\circ} \mathrm{C}(\mathrm{Fig} .9 \mathrm{e}$, g). Globularization of SLM-produced Ti-6Al-4V (Fig. 9b, d, f, h) occurs slower - during deformation in ( $a+$ $\beta)$-field, thickness of a-laths increases gradually. This can be related to inhomogeneous deformation of SLM-produced Ti-6Al-4V.

For wrought Ti-6Al-4V alloy, Vickers microhardness $\mathrm{HV}$ is 313.2 after deformation at temperature of $800{ }^{\circ} \mathrm{C}, 313.8$ - after deformation at temperature of $900^{\circ} \mathrm{C}$. For SLM-produced Ti-6Al-4V, Vickers microhardness $\mathrm{HV}$ is 375 after deformation at temperature of $800{ }^{\circ} \mathrm{C}, 361.4$ - after deformation at temperature of $900^{\circ} \mathrm{C}$. As we can see, Vickers microhardness of wrought Ti-6Al-4V alloy after deformation at temperatures of 800 and $900{ }^{\circ} \mathrm{C}$ decreased, which was expected. Vickers microhardness of SLM-produced Ti-6Al-4V alloy slightly decreased after deformation at temperature of $900{ }^{\circ} \mathrm{C}$. The results of Vickers microhardness measurements of SLM-produced Ti-6Al-4V after deformation at temperature of $800^{\circ} \mathrm{C}$, whose values turned out to be higher than the initial ones, was unexpected. This can be explained by the fact that the deformation took place below the recrystallization temperature and by significant deformation inhomogeneity caused by the high temperature sensitivity of the material at this temperature.

\section{Conclusions}

In this research work, the study of rheological properties, flow behaviour and microstructure evolution of SLM-produced and conventional wrought Ti-6Al-4V titanium alloy in the temperature range of 20-1200 ${ }^{\circ} \mathrm{C}$ and at strain rate $\xi$ of $1 \mathrm{~s}^{-1}$ was performed. Study shows that flow stresses of as-built SLM-produced material higher than that of conventional wrought in the temperature range from 600 to $900{ }^{\circ} \mathrm{C}$. At these temperatures flow behaviour of SLM and wrought material is different - SLM-produced Ti-6Al-4V shows pronounced peak stress with subsequent long stage of softening. Differences in the values of flow stresses and flow behaviour of SLM-produced and conventional wrought materials are explained by their different initial microstructure.

At temperatures of $600-800^{\circ} \mathrm{C}$, an extremely non-uniform deformation of SLM samples occurs, while deformation of wrought material in the whole temperature range of $400-1200{ }^{\circ} \mathrm{C}$ was quite uniform. High deformation instability of SLM material compared to wrought is consequence of both its high temperature sensitivity and softening rate. In view of this it is necessary to control the temperature in the deformation zone for the processes of deformation post-treatment in-situ (plastic deformation of each built-up layers) and apply isothermal die forging for the processing route "SLM + hot forming".

As a direction of the further research work, the study of dependence of flow stresses of SLM-produced Ti6Al-4V alloy from SLM-process parameters (laser power, scanning strategy) and post-annealing parameters of SLM-produced samples can be pointed out.

\section{Declarations}


Authors' contributions Not applicable

\section{Funding}

The study was made within the basic part of the state job in the field of scientific activity No. 0836-20200020 and was supported by Act 211 of the Government of the Russian Federation (agreement No. 02.A03.21.0006).

The equipment of the "Plastometriya" collective use center was used in the research.

Data availability Not applicable

\section{Compliance with ethical standards}

Competing interests The authors declare that they have no conflict of interest.

\section{References}

1. Abdel Ghany K, Moustafa SF (2006) Comparison between the products of four RPM systems for metals. Rapid Prototyping Journal 12(2):86-94

2. Herzog D, Seyda V, Wycisk E, Emmelmann C (2016) Additive manufacturing of metals. Acta Mater 117:371-392

3. Kranz J, Herzog D, Emmelmann C (2015) Design guidelines for laser additive manufacturing of lightweight structures in TiAl6V4. Journal of Laser Applications 27:1-16

4. Appleyard D (2015) Powering up on powder technology. Met Powder Rep 70(6):285-289

5. Tan X, Kok Y, Tan YJ et al (2015) Graded microstructure and mechanical properties of additive manufactured Ti-6Al-4V via electron beam melting. Acta Mater 97:1-16

6. Murr LE, Esquivel EV, Quinones SA et al (2009) Microstructures and mechanical properties of electron beam-rapid manufactured $\mathrm{Ti}-6 \mathrm{Al}-4 \mathrm{~V}$ biomedical prototypes compared to wrought $\mathrm{Ti}-6 \mathrm{Al}-4 \mathrm{~V}$. Mater Charact 60(2):96-105

7. Wycisk E, Siddique S, Herzog D, Walther F, Emmelmann C (2015) Fatigue performance of laser additive manufactured Ti-6Al-4V in very high cycle fatigue regime up to 109 cycles. Frontiers in Materials 2:1-8

8. Kasperovich G, Hausmann J (2015) Improvement of fatigue resistance and ductility of TiAl6V4 processed by selective laser melting. J Mater Process Technol 220:202-214

9. Liu Sh, Shin YC (2019) Additive manufacturing of Ti6Al4V alloy: A review. Mater Des 164:1-23

10. Chunxiang C, BaoMin H, Lichen Zh, Shuangjin L (2011) Titanium alloy production technology, market prospects and industry development. Mater Des 32:1684-1691

11. Qiu C, Adkins NJE, Attallah MM (2013) Microstructure and tensile properties of selectively lasermelted and of HIPed laser-melted Ti-6Al-4V. Materials Science Engineering A 578:230-239 
12. Wycisk E, Solbach A, Siddique S et al (2014) Effects of Defects in Laser Additive Manufactured Ti6Al-4V on Fatigue Properties. Physics Procedia 56:371-378

13. Edwards P, Ramulu M (2014) Fatigue performance evaluation of selective laser melted Ti-6Al-4V. Materials Science Engineering A 598:327-337

14. Yasa E, Deckers J, Kruth J-P (2011) The investigation of the influence of laser re-melting on density, surface quality and microstructure of selective laser melting parts. Rapid Prototyping Journal 17(5):312-327

15. Facchini L, Magalini E, Robotti P (2010) Ductility of a Ti-6Al-4V alloy produced by selective laser melting of prealloyed powders. Rapid Prototyping Journal 16(6):450-459

16. Yan X, Yin Sh, Chen Ch et al (2018) Effect of heat treatment on the phase transformation and mechanical properties of Ti6Al4V fabricated by selective laser melting. J Alloy Compd 764:10561071

17. Beese AM, Carroll BE (2016) Review of mechanical properties of Ti-6Al-4V made by laser-based additive manufacturing using powder feedstock. JOM 68(3):724-734

18. Loginov YuN, Stepanov SI, Yudin AV, Tretyakov EV (2018) Relationship between mechanical properties and density of Ti obtained by additive technology. Tsvetnye Metally 5:51-55

19. Golodnov Al, Loginov YuN, Stepanov SI (2018) Numeric Loading Simulation of Titanium Implant Manufactured using 3D Printing. Solid State Phenom 284:380-385

20. Hollander DA, Walter M, Wirtz T et al (2006) Structural, mechanical and in vitro characterization of individually structured Ti-6Al-4V produced by direct laser forming. Biomaterials 27(7):955-963

21. Wysocki B, Maj P, Sitek R et al (2017) Laser and Electron Beam Additive Manufacturing Methods of Fabricating Titanium Bone Implants. Applied Sciences 7(7):1-20

22. Vilaro T, Colin C, Bartout JD (2011) As-Fabricated and Heat-Treated Microstructures of the Ti-6Al-4V Alloy Processed by Selective Laser Melting. Metall Mater Trans A 42(10):3190-3199

23. Vrancken B, Thijs L, Kruth J-P, Humbeeck JV (2012) Heat treatment of Ti6Al4V produced by Selective Laser Melting: Microstructure and mechanical properties. J Alloy Compd 541:177-185

24. Rafi HK, Karthik NV, Gong H, Starr TL, Stucker BE (2013) Microstructures and Mechanical Properties of Ti6Al4V Parts Fabricated by Selective Laser Melting and Electron Beam Melting. J Mater Eng Perform 22(12):3872-3883

25. Simonelli M, Tse YY, Tuck C (2014) Effect of the build orientation on the mechanical properties and fracture modes of SLM Ti-6Al-4V. Mater Sci Eng A 616:1-11

26. Leuders S, Thöne M, Riemer A et al (2013) On the mechanical behaviour of titanium alloy TiAl6V4 manufactured by selective laser melting: Fatigue resistance and crack growth performance. Int $\mathrm{J}$ Fatigue 48:300-307

27. Chastand V, Quaegebeur P, Maia W, Charkaluk E (2018) Comparative study of fatigue properties of Ti$6 \mathrm{Al}-4 \mathrm{~V}$ specimens built by electron beam melting (EBM) and selective laser melting (SLM). Material Characterization 143:76-81 
28. Koike M, Greer P, Owen K (2011) Evaluation of Titanium Alloys Fabricated Using Rapid Prototyping Technologies - Electron Beam Melting and Laser Beam Melting. Materials 4(10):1776-1792

29. Dutta B, Froes FH (2017) The Additive Manufacturing (AM) of titanium alloys. Met Powder Rep 72:96-106

30. Zhang M, Liu C, Shi X (2016) Residual Stress, Defects and Grain Morphology of Ti-6Al-4V Alloy Produced by Ultrasonic Impact Treatment Assisted Selective Laser Melting. Applied sciences 6(11):1-7

31. Williams SW, Martina F, Addison AC (2016) Wire + Arc Additive Manufacturing. Mater Sci Technol 32(7):641-647

32. Sames WJ, List FA, Pannala S, Dehoff RR, Babu SS (2016) The metallurgy and processing science of metal additive manufacturing. Int Mater Rev 61(5):315-360

33. Friel RJ, Harris R (2013) Ultrasonic additive manufacturing. A hybrid production process for novel functional products. Procedia CIRP 6:35-40

34. Gladkovsky SV, Salikhyanov DR, Volkov VP, Avaraamov YA, Veselova VE (2020) Rheological Properties and Microstructure of PH1 Stainless Steel Produced by Selective Laser Melting. Mater Sci Forum 989:811-815

35. Salikhyanov DR, Gladkovsky SV, Volkov VP, Avaraamov YA, Veselova VE (2020) Rheological Properties and Microstructure of AlSi10Mg Aluminum Alloy produced by Selective Laser Melting. IOP Conference Series: Materials Science and Engineering 709:1-6

36. Duarte VR, Rodrigues TA, Schell N et al (2020) Hot Forging Wire and Arc Additive Manufacturing (HFWAAM). Additive Manufacturing 35:1-10

37. Semiatin SL, Kobryn PA, Roush ED et al (2001) Plastic flow and microstructure evolution during thermomechanical processing of laser-deposited Ti-6Al-4V preforms. Metall Mater Trans A 32(7):1801-1811

38. Sizova I, Bambach M (2018) Hot workability and microstructure evolution of pre-forms for forgings produced by additive manufacturing. J Mater Process Technol 256:154-159

39. Bambach M, Sizova I, Emdadi A (2019) Development of a processing route for Ti-6Al-4V forgings based on preforms made by selective laser melting. Journal of Manufacturing Processes 37:150158

40. Semiatin SL, Seetharaman V, Weiss I (1999) Flow behavior and globularization kinetics during hot working of Ti-6Al-4V with a colony alpha microstructure. Mater Sci Eng A 263:257-271

41. Guan RG, Je YT, Zhao ZhY, Lee ChS (2012) Effect of microstructure on deformation behavior of Ti$6 \mathrm{Al}-4 \mathrm{~V}$ alloy during compressing process. Mater Des 36:796-803

42. Perumal B, Rist MA, Gungor S, Brooks JW, Fitzpatrick ME (2016) The Effect of Hot Deformation Parameters on Microstructure Evolution of the a-Phase in Ti-6Al-4V. Metall Mater Trans A 47:41284136 
43. Lee RS, Lin HC (1998) Process design based on the deformation mechanism for the non-isothermal forging of Ti-6Al-4V alloy. J Mater Process Technol 79:224-235

44. Semiatin SL, Bieler TR (2001) The effect of Alpha platelet thickness on plastic flow during hot working of Ti-6Al-4V with a transformed microstructure. Acta Mater 49:3565-3573

45. Dziubińska A, Majerski K, Winiarski G (2017) Investigation of the effect of forging temperature on the microstructure of grade 5 titanium ELI. Advances in Science Technology 11(4):147-158

46. Luo J, Li M, Li H, Yu W (2009) Effect of the strain on the deformation behavior of isothermally compressed Ti-6Al-4V alloy. Mater Sci Eng A 505:88-95

47. Stolyarov VV (2010) Structure and properties of ultrafine-grained VT6 titanium alloy obtained by equal-channel angular pressing. Mechanical Engineering Engineering Education 2:30-36 (in Russian)

48. Potapov Al, Kharitonin SV (2013) Deformation resistance of titanium alloys at temperatures of warm and hot metal forming. Zagotovitelnye proizvodstva v mashinostroenii 3:18-22 (in Russian)

49. Polukhin PI, Gun GYa, Galkin AM (1983) Deformation resistance of metals and alloys. 2nd ed. and add. Handbook. Metallurgiya, Moscow 352 (in Russian)

50. Krivickiy BA, Arsenteva KS (2014) To the method of determining the rheological properties of metals by torsion tests. Izvestiya vuzov Cvetnaya metallurgiya 6:34-37 (in Russian)

51. Mamedova A, Ozturka H, Makasa T (2017) Investigation of Mechanical and Microstructural Properties of Ti-6Al-4V Alloy Depending on Hot Forging Process Parameters. Procedia Eng 207:2155-2160

52. Loginov YuN, Gladkovskii SV, Potapov Al et al (2015) Investigation into the Deformation Resistance of Polycrystalline Iridium. Russian Journal of Non-Ferrous Metals 56(5):532-539

53. Gladkovskii SV, Potapov Al, Salikhyanov DR (2018) Rheological Properties and Substantiation of Hot Rolling Regimes of Low- and Medium Carbon Structural Steels. Solid State Phenom 284:653-661

54. Popovich AA, Sufiyarov VSh, Borisov EV et al (2016) Anisotropy of mechanical properties of products produced by selective laser melting method of powder materials. Teoriya i processy formovaniya i spekaniya poroshkovyh materialov 3:4-11 (in Russian)

55. Miller RM, Bieler TR, Semiatin SL (1999) Flow softening during hot working of Ti-6Al-4V with a lamellar colony microstructure. Scripta Mater 40:1387-1393

56. Li P-H, Guo W-G, Huang W-D (2015) Thermomechanical response of 3D laser-deposited Ti-6Al-4V alloy over a wide range of strain rates and temperatures. Mater Sci Eng A 647:34-42

57. Biswas N, Ding JL, Balla VK, Field DP, Bandyopadhyay A (2012) Deformation and fracture behavior of laser processed dense and porous Ti6Al4V alloy under static and dynamic loading. Mater Sci Eng A 549:213-221

58. Loginov YuN, Ershov AA (2012) The effect of the hardening curve type on localization of deformation during upsetting of titanium billets. Titan 35(1):22-28 (in Russian) 


\section{Tables}

Table 1

Mechanical properties of SLM-produced Ti-6Al-4V alloy with or without subsequent post-treatment compared to cast and wrought Ti-6Al-4V [8, 9, $11,12,13,15,16,20-28]$

\begin{tabular}{|c|c|c|c|c|}
\hline $\begin{array}{c}\text { Manufacturing condition } \\
\text { of Ti-6Al-4V alloy }\end{array}$ & $\begin{array}{c}\text { Yield } \\
\text { strength, } \\
\text { MPA }\end{array}$ & $\begin{array}{c}\text { Ultimate tensile } \\
\text { strength, MPa }\end{array}$ & Elongation & $\begin{array}{c}\text { Mean fatigue } \\
\text { life, cycles } \\
\text { number }\end{array}$ \\
\hline $\begin{array}{c}\text { SLM, as-built, not- } \\
\text { machined }\end{array}$ & $664-910$ & $960-1062$ & $3.3-12.7$ & $\begin{array}{c}2.3 \times 10^{3}- \\
5.6 \times 10^{3}\end{array}$ \\
\hline $\begin{array}{c}\text { SLM, as-built, machined } \\
\text { SLM, stress-relieved, } \\
\text { machined }\end{array}$ & $962-1273$ & $1095-1421$ & $1.4-12.3$ & $\begin{array}{c}1.2 \times 10^{4}- \\
2.0 \times 10^{4}\end{array}$ \\
\hline $\begin{array}{c}\text { SLM, annealed, machined } \\
\text { pressed, machined }\end{array}$ & $798-1045$ & $945-1115$ & $5.0-13.0$ & - \\
\hline $\begin{array}{c}\text { Wrought, as-received } \\
\text { SLostatically }\end{array}$ & $790-9672$ & $973-1005$ & $8.3-19.4$ & $\begin{array}{c}1.5 \times 10^{5}- \\
3.0 \times 10^{5}\end{array}$ \\
\hline Wrought, mill-annealed & $960-970$ & $1006-1030$ & $16-18.37$ & $1.1 \times 10^{5}-$ \\
\hline Cast & $750-865$ & $875-980$ & $4.5-13.5$ & - \\
\hline
\end{tabular}

Table 2

Chemical composition of Ti-6Al-4V titanium alloy produced by SLM and conventional technology

\begin{tabular}{|c|c|c|c|c|c|c|c|c|c|c|c|}
\hline \multirow{2}{*}{ Alloy } & \multicolumn{10}{|c|}{ Chemical composition, wt. \% } \\
\cline { 2 - 11 } & $\mathrm{Ti}$ & $\mathrm{Al}$ & $\mathrm{V}$ & $\mathrm{O}$ & $\mathrm{N}$ & $\mathrm{C}$ & $\mathrm{H}$ & $\mathrm{Fe}$ & $\mathrm{Si}$ & $\mathrm{Zr}$ & Impurities \\
\hline Ti-6Al-4V & Bal. & $5.5-$ & $3.5-$ & $\mathrm{Up}$ & $\mathrm{Up}$ & $\mathrm{Up}$ & $\mathrm{Up}$ to & $\mathrm{Up}$ & - & - & Rest 0.3 \\
(SLM) & & 6.75 & 4.5 & to & to & to & 0.015 & to & & & \\
& & & & 0.2 & 0.05 & 0.08 & & 0.3 & & & \\
\hline VT6 & Bal. & 5.3 & 3.5 & $\mathrm{Up}$ & $\mathrm{Up}$ & $\mathrm{Up}$ & $\mathrm{Up}$ to & $\mathrm{Up}$ & $\mathrm{Up}$ & $\mathrm{Up}$ & Rest 0.3 \\
(conventional & & - & - & to & to & to & 0.015 & to & to & to & \\
wrought) & & 6.8 & 5.3 & 0.2 & 0.05 & 0.1 & & 0.3 & 0.15 & 0.3 & \\
\hline
\end{tabular}

\section{Figures}




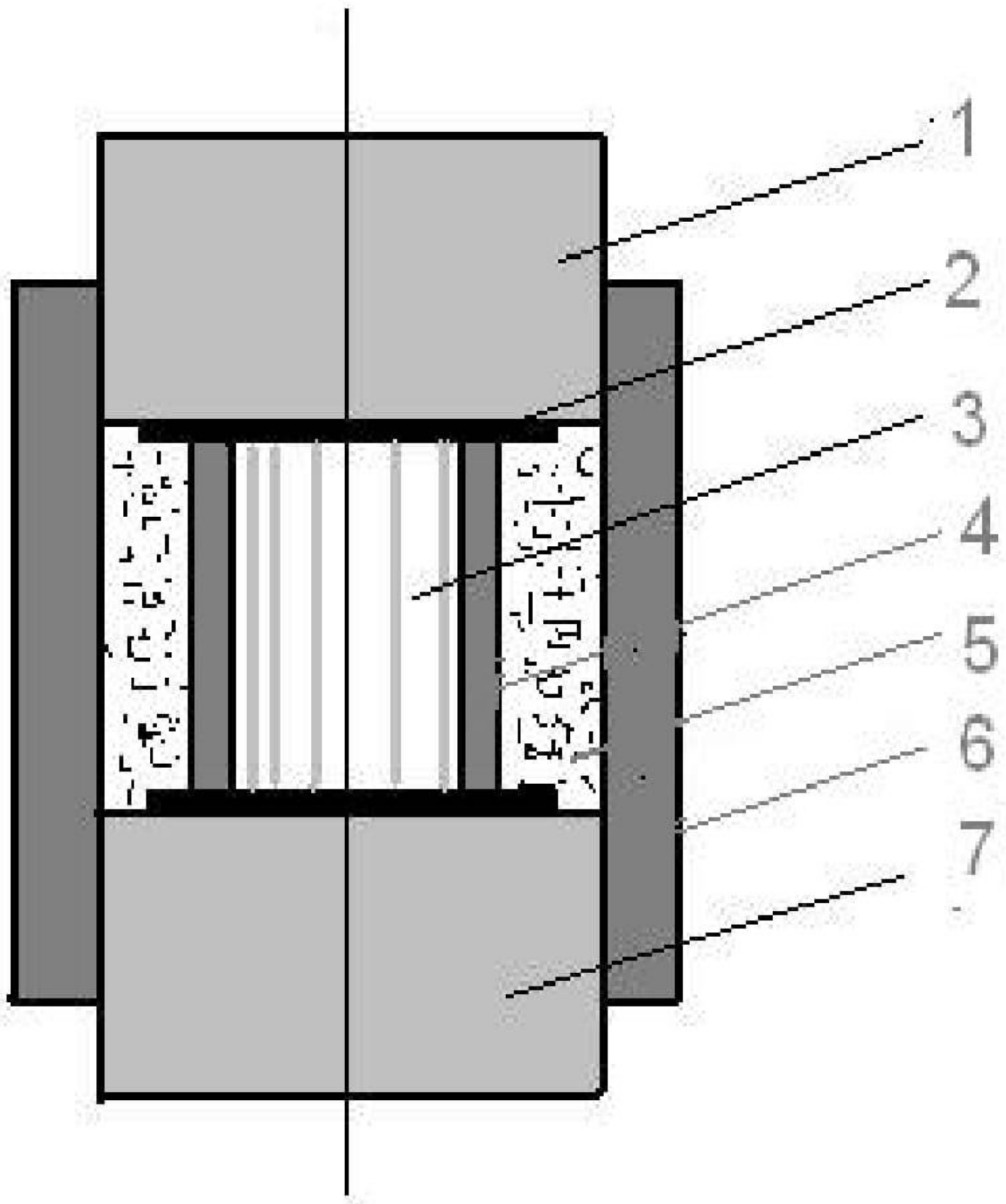

Figure 1

Assembly scheme of a container with a sample for compression: 1 - upper deforming anvil; 2 - lubricant layer; 3 - sample; 4 - asbestos insulation; 5 - kaolin wadding; 6 - steel container; 7 - lower deforming anvil 


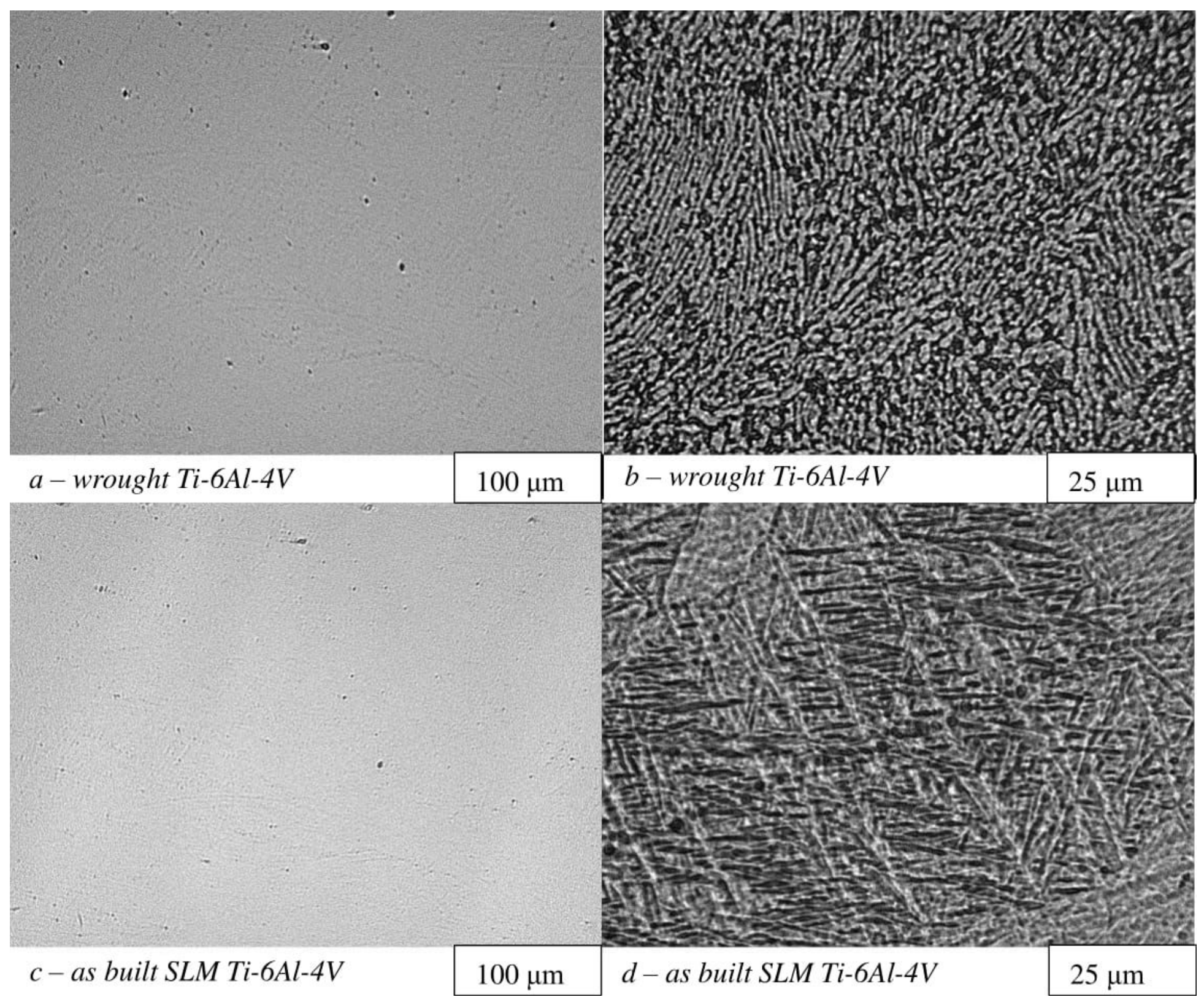

Figure 2

Microstructure of conventional wrought ( $a$ - without etching, $x 100, b-$ with etching, $x 400$ ) and SLMproduced ( $c$ - without etching, $x 100, d-$ with etching, $x 400)$ Ti-6Al-4V alloy 

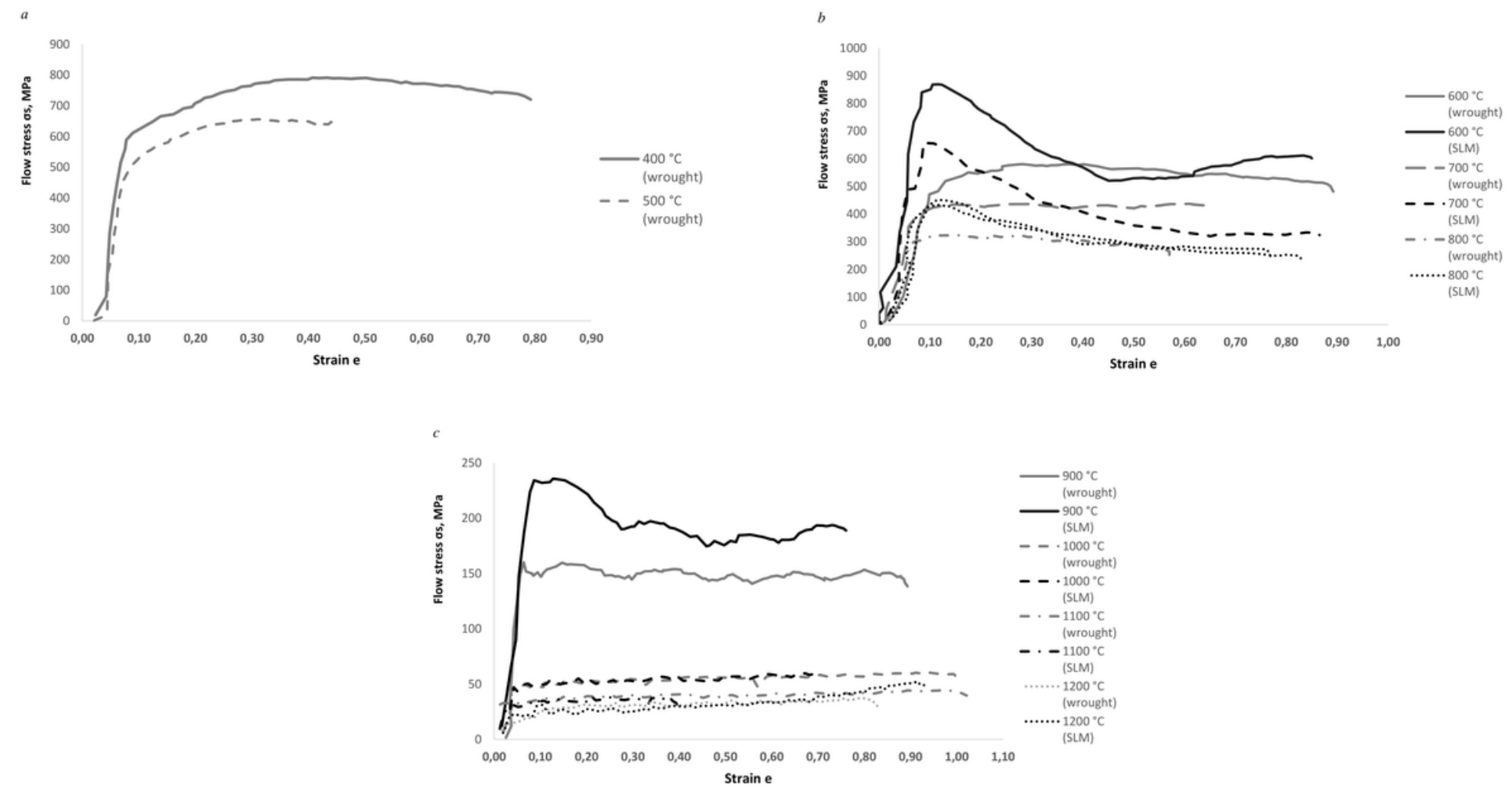

\section{Figure 3}

The flow curves of SLM-produced and wrought Ti-6Al-4V titanium alloy at temperatures of cold $400-$ $500{ }^{\circ} \mathrm{C}(\mathrm{a}), 600-800{ }^{\circ} \mathrm{C}(\mathrm{b})$, and hot deformation $900-1200{ }^{\circ} \mathrm{C}(\mathrm{c})$ 


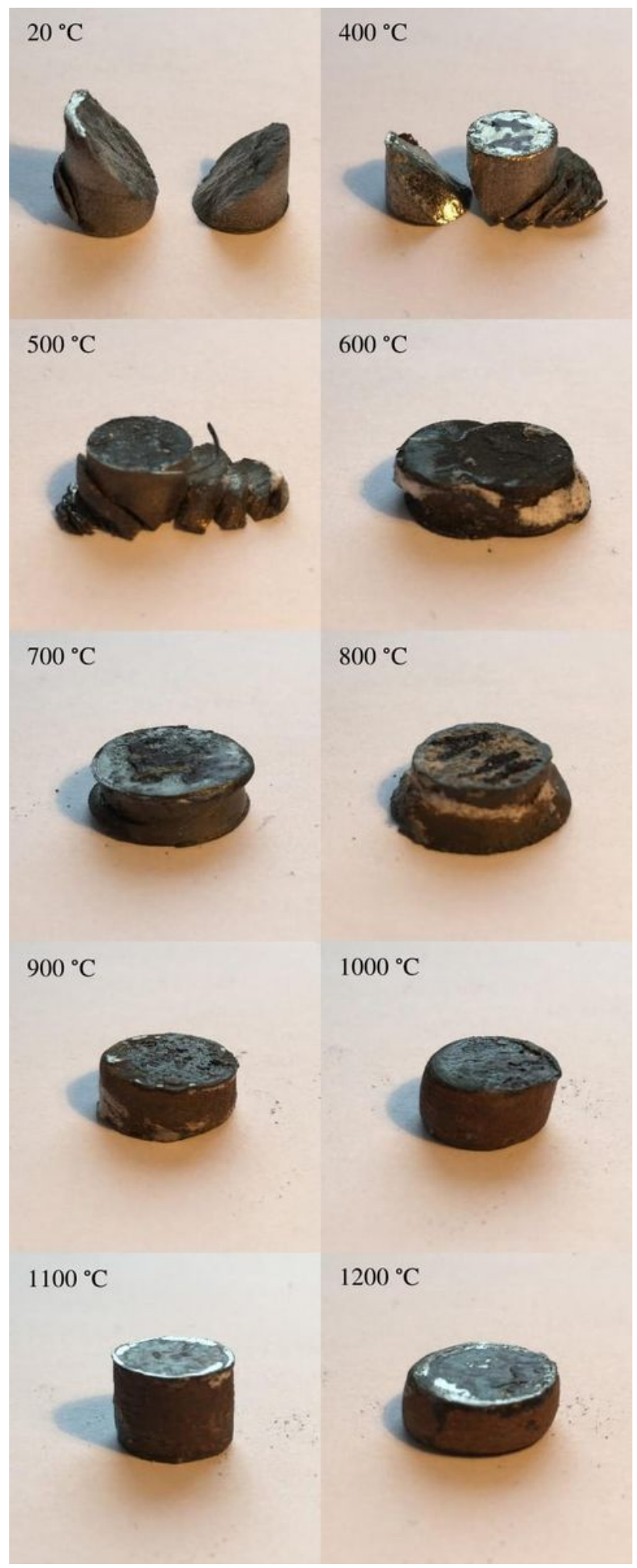

Figure 4

General view of samples from SLM-produced Ti-6Al-4V titanium alloy after deformation in the temperature range of $20-1200{ }^{\circ} \mathrm{C}$ 


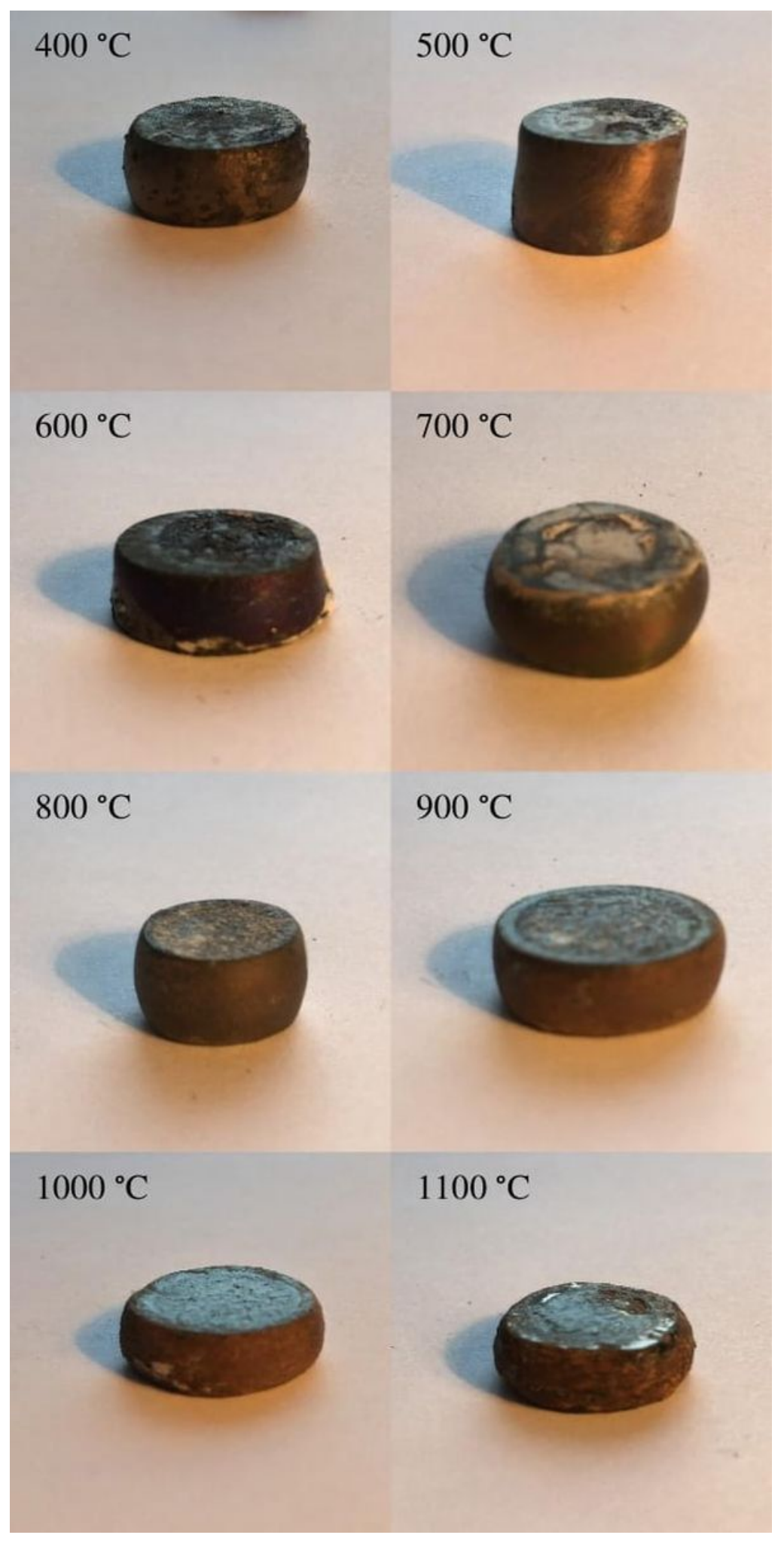

Figure 5

General view of samples from wrought Ti-6Al-4V titanium alloy after deformation in the temperature range of $400-1100{ }^{\circ} \mathrm{C}$ 


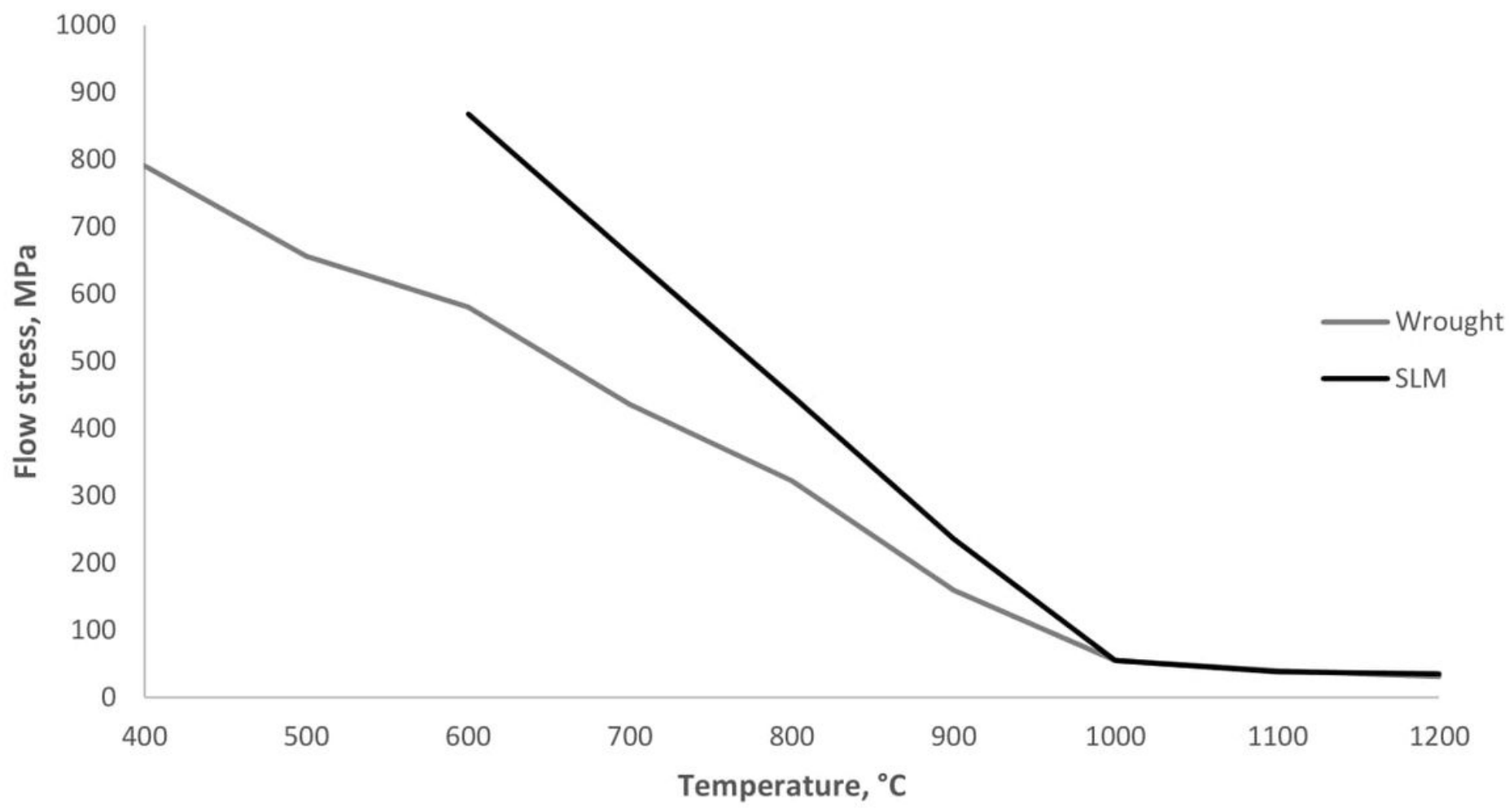

Figure 6

Flow stress (peak stress) as a function of temperature of SLM-produced and wrought Ti-6Al-4V

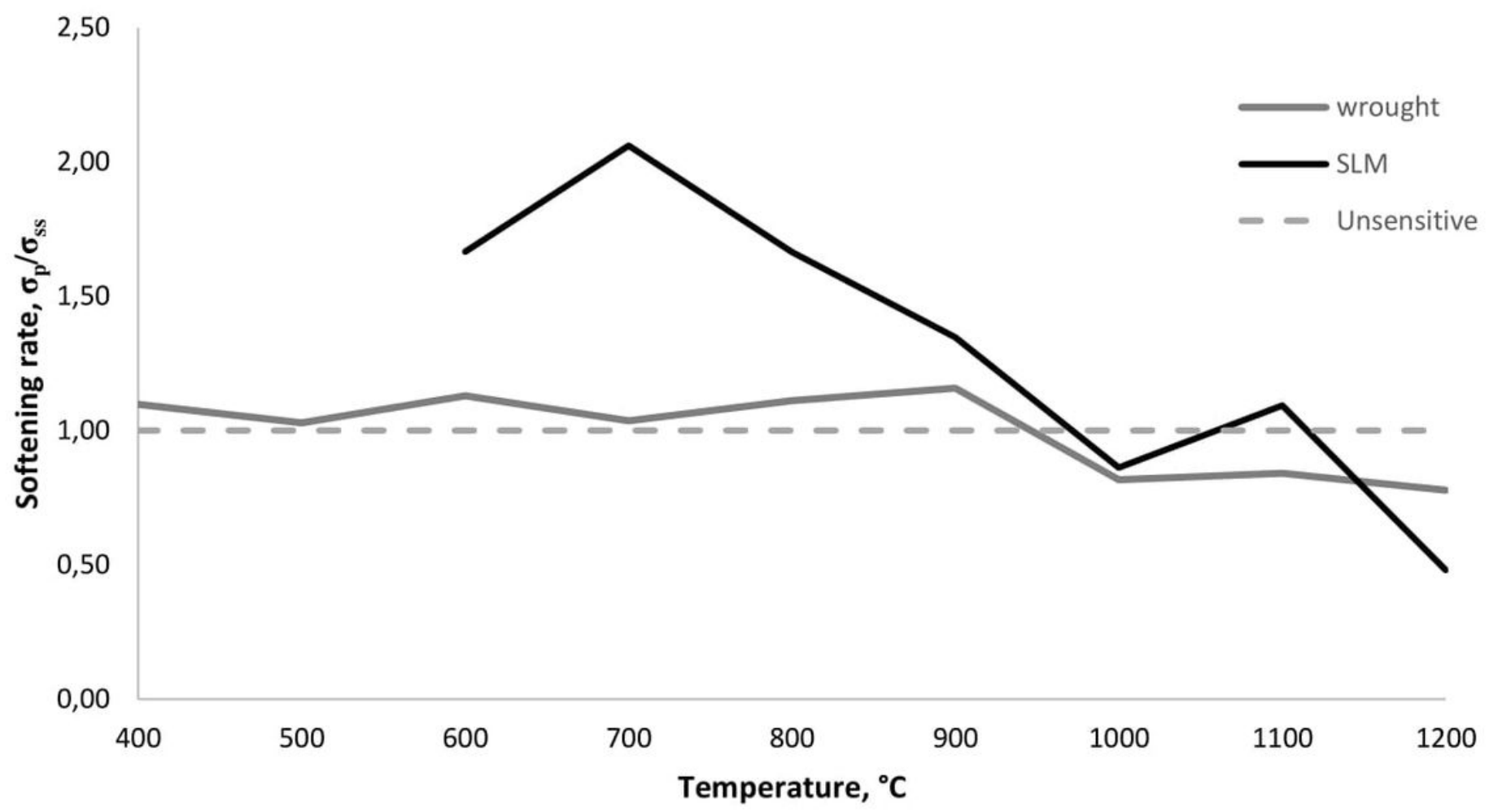

Figure 7 
Softening rate of SLM-produced and wrought Ti-6Al-4V

$a$-wrought Ti-6Al-4V

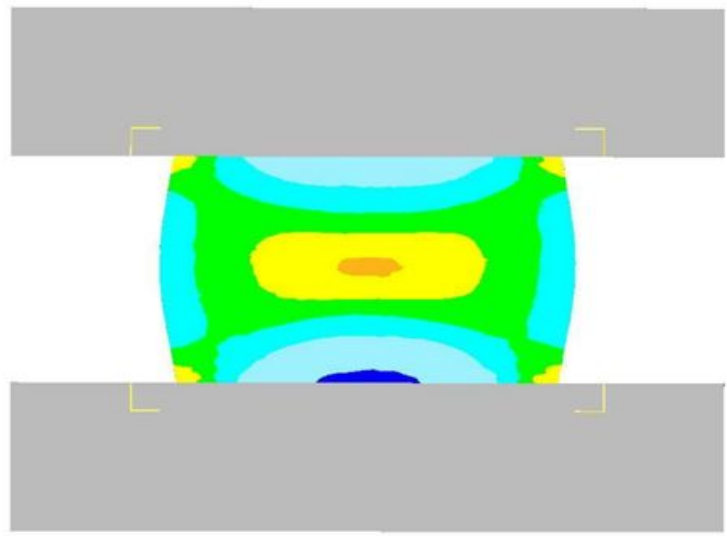

$b-S L M T i-6 A l-4 V$

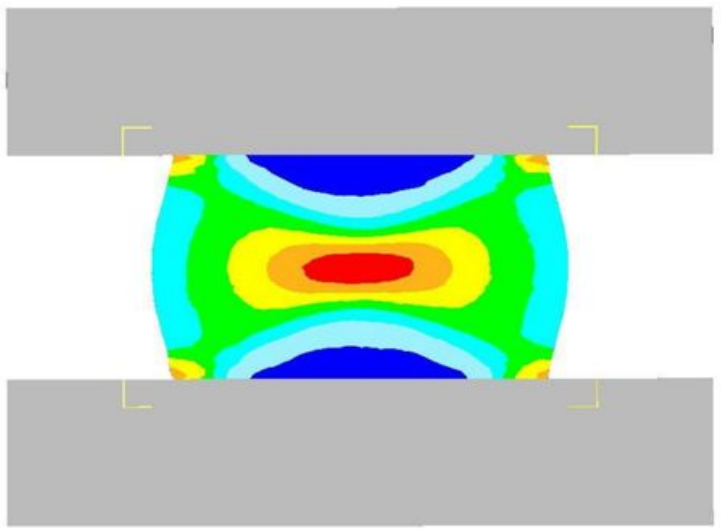

Strain - Effective $(\mathrm{mm} / \mathrm{mm})$

1.20
1.05
0.900
0.750
0.600
0.450
0.300
0.150
0.000

Figure 8

Deformation gradient of wrought (a) and SLM-produced (b) Ti-6Al-4V alloy 

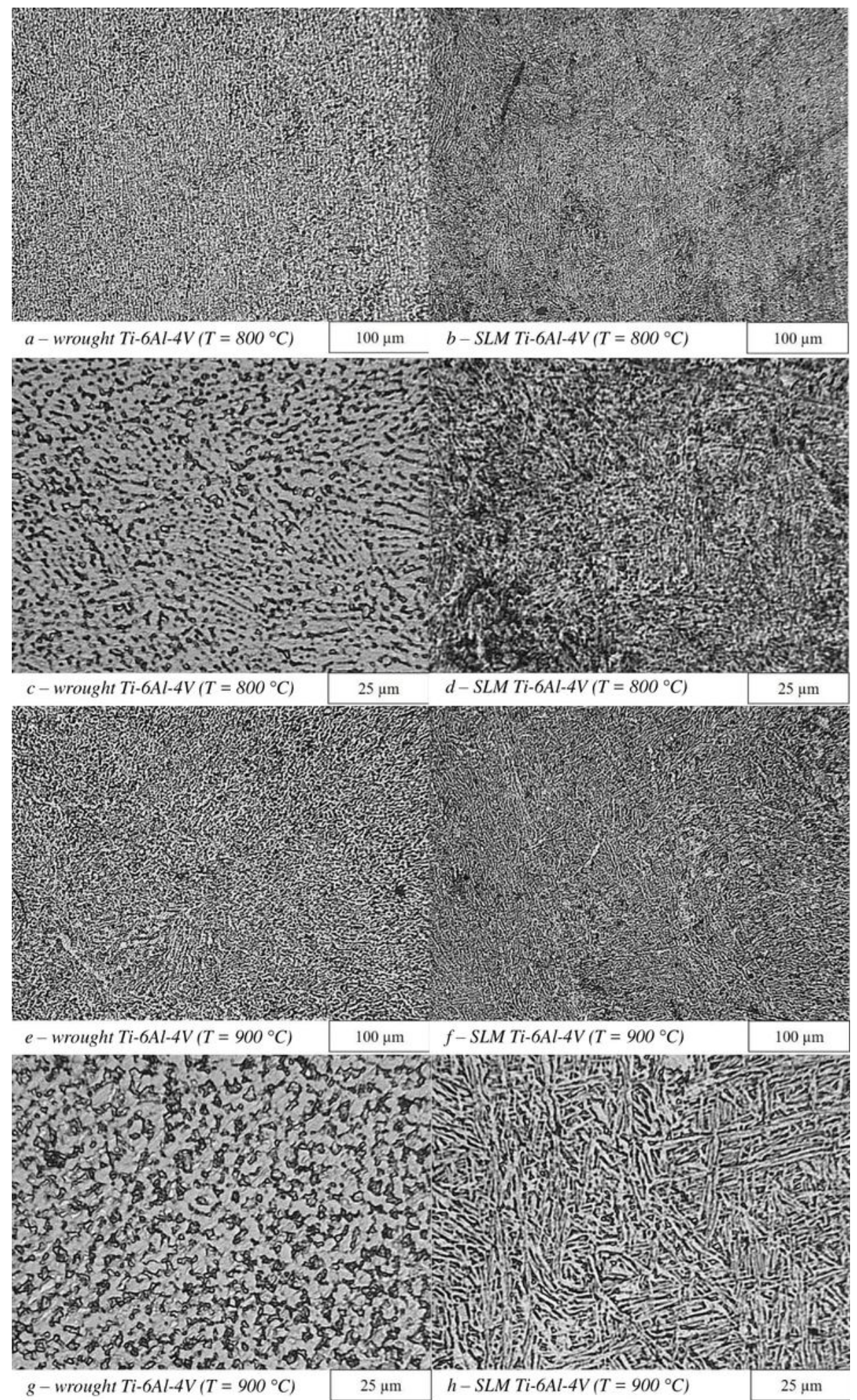

\section{Figure 9}

Microstructure of Ti-6Al-4V after deformation: conventional wrought $(\mathrm{a}, \mathrm{c}, \mathrm{e}, \mathrm{g})$ at temperature of $800^{\circ} \mathrm{C}$ $(a, c)$ and at temperature of $900{ }^{\circ} \mathrm{C}(e, g)$; SLM-produced $(b, d, f, h)$ at temperature of $800{ }^{\circ} \mathrm{C}(b, d)$ and at temperature of $900{ }^{\circ} \mathrm{C}(f, h)$; magnification of $x 100-a, b, e, f ; x 400-c, d, g, h$ 